\title{
That Sounds More Like Something Aarfy Would Do: Conflicting Portrayals of Sexual Assault in Catch-22 and Something Happened
}

Ian M. Rogers

\section{(2) OpenEdition Journals}

Electronic version

URL: https://journals.openedition.org/ejas/16924

DOI: $10.4000 /$ ejas. 16924

ISSN: 1991-9336

Publisher

European Association for American Studies

Electronic reference

Ian M. Rogers, "That Sounds More Like Something Aarfy Would Do: Conflicting Portrayals of Sexual Assault in Catch-22 and Something Happened", European journal of American studies [Online], 16-2 | 2021 Online since 13 July 2021, connection on 17 October 2022. URL: http://journals.openedition.org/ejas/ 16924 ; DOI: https://doi.org/10.4000/ejas. 16924

This text was automatically generated on 17 October 2022.

\section{(c) (i) (9)}

Creative Commons - Attribution-NonCommercial 4.0 International - CC BY-NC 4.0 https://creativecommons.org/licenses/by-nc/4.0/ 


\title{
That Sounds More Like Something Aarfy Would Do: Conflicting Portrayals of Sexual Assault in Catch-22 and Something Happened
}

\author{
Ian M. Rogers
}

\section{The Problem of Catch-22 in the \#MeToo Era}

1 “That's not your liver," Nurse Duckett tells Yossarian in the 2019 Catch-22 miniseries during their first scene together. Whereas in Joseph Heller's 1961 novel the deathaverse Yossarian can check into the hospital with a fake liver ailment whenever he wants, the miniseries shows him being questioned by a well-informed Nurse Duckett about his alleged pain and unable to pinpoint it to his liver. Her character, played by Tessa Ferrer, eventually submits to Yossarian's charade and goes on to serve as his knowledgeable confidant and foil, in contrast to the novel where her role is limited to intimate liaisons on the beach. The decision to give at least one of Catch-22's female characters more depth and agency was necessary in a novel where at best women are relegated to background characters and at worst they serve as objects of sexual fulfillment for the male characters. While little has been written by scholars regarding Heller's treatment of sexual assault or women in Catch-22, media reviews of the miniseries unequivocally condemned the negative portrayals of women in the original novel, calling them "terrible" (Holloway), "misogynistic" (Moore), a "threadbare portrayal of women as two dimensional, objectified non-characters" (Miller), and noting that "some of what the book treats lightly would be rightly recognized as sexual assault today" (Lloyd). Heller himself even acknowledged his own sexism in a 1996 interview, calling his 1994 novel Closing Time the first time in his work that "women are consistently treated with respect" (Reilly 511). 
Indeed, Heller's portrayals of women in Catch-22 feel insulting and demeaning in the \#MeToo era, especially compared to his more revealing satires of bureaucracy and power abuses. Yossarian's squadron-mate Hungry Joe, for instance, responds to women as "sexual beings" with a reaction of "frenzied worship and idolatry" (53) and is obsessed with capturing nude women on film under the pretense of being a magazine photographer. Lieutenant Scheisskopf's wife is initially described in terms of her undressing "for every cadet in her husband's squadron who wanted to creep into her" (71), and only later do readers learn that she "read good books" (72), leaving her intellectual abilities as an afterthought. Perhaps most alarming, however, is a troubling instance of violence against women when Yossarian and Dunbar assault Nurse Duckett in the hospital, a scene played for laughs that completely ignores the severity of the crime committed. The scene's flippant treatment of sexual assault not only conflicts with contemporary readers' notions of consent and rape, more perplexingly, for twenty-first-century readers it conflicts with Heller's own unambiguously condemning portrayals of violence against women elsewhere in the novel. These condemnations are made explicit during the Eternal City night walk, which portrays sexual violence as a horrifying embodiment of an unjust power balance where abusers of women escape punishment through their status as respectable members of society. While several scholars have explored Heller's use of assault to horrify readers and exemplify the devastation wrought by invading armies against the weak (Doskow 191, Sanborn 423), these studies fail to include Yossarian's assault on Nurse Duckett in their discussions, raising the question of how readers should approach sexual assault in Catch-22 as a whole.

3 This essay argues that rather than forming a unified thematic treatment of violence against women, the incidents of sexual assault in Catch-22 are best discussed separately in a manner that acknowledges their contradictions. The first section examines Heller's obliviousness to the suffering of a female victim during the Nurse Duckett assault, with the incident exemplifying an unrebuked abuse of male power. The second section discusses the clearer power abuses portrayed in the Eternal City rapes, though it argues that because these rapes are viewed solely from the perspective of an observer rather than that of the victims, they ultimately amount to little more than heart-stirring tragedies. The third section examines Heller's portrayal of Aarfy as a serial abuser of women, along with characteristics that place him on the upper end of Heller's unjust power dynamic with continued implications for how we characterize perpetrators of sexual assault today. The final section examines an instance of assault in Heller's second novel, Something Happened, where the rape of Virginia Markowitz more holistically combines the horrors of rape as power abuse with fuller and more sympathetic insight into the victim's experience compared with the assaults in Catch-22. Because Something Happened deals with similar themes of power abuse and toxic masculinity, Heller's treatment of Virginia's rape and its aftermath presents a view of what the assaults in Catch-22 might look like if they were more consistently assembled to embody these dynamics, and serves as a more reliable indicator of how assault fits into Heller's treatment of power abuses in the bureaucracies of the corporate world and elsewhere.

These conflicting portrayals of assault are worth examining because to ignore their contradictions is to risk either condemning Catch-22 as misogynistic, or embracing the opposite extreme by overlooking the Nurse Duckett assault and Heller's superficial 
portrayals of women. It is only by isolating and discussing these instances individually can contemporary readers gain a fuller understanding of Heller's treatment of women in Catch-22 and elsewhere.

\section{The Assault on Nurse Duckett as an Unrebuked Abuse of Male Power}

5 Catch-22 is a war novel where horrifying and gruesome deaths befall its characters, but rather than framing these deaths as the travesties of an enemy nation, Heller places blame on those in command on the American side who abuse their authority through either stupidity or lust for power. Such satirical attacks on powerful authority figures can be seen in Colonel Cathcart, who wants his men to risk their lives flying extra missions so he can get his picture in the Saturday Evening Post; Lieutenant Scheisskopf, who is obsessed with parade formations and wants to chain his men's wrists to their thighbones to ensure the proper amount of swing; and Milo Minderbinder, whose unchecked drive for capitalistic profit leads to the bombing of his own base. In this respect Heller can be viewed as one of many early- to mid-twentieth-century novelists such as Steinbeck, Dos Passos, and Dreiser who, driven by social indignation, struck out against monumental and corrupt establishments in support of the masses (Way 253). To achieve this end, James Nagel notes in his study of satire in Catch-22 that Heller's attacks on "definable groups within American society" create "a unified front against a corrupt and ridiculous enemy" ("Angry Humor" 100). By portraying those who embody stupidity and wickedness as both fools and knaves, "a sympathetic reader, laughing at the satirized subjects, feels himself to be a member of a select aristocracy based on virtue and intelligence" (100). Such a dichotomy occurs as long as characters who cause human suffering (Colonel Cathcart, Lieutenant Scheisskopf, and others) fall on the villainous, detestable side, and characters who suffer hardships (Yossarian, Chaplain Tappman, Dunbar, Snowden, and others) fall on the virtuous, intelligent side, thus gaining readers' sympathy as victims with whom they can feel camaraderie.

This dichotomy, however, breaks down when characters we've initially placed on the virtuous and victimized side commit wrongs of their own, as when Yossarian and Dunbar assault Nurse Duckett at the hospital. The scene is worth quoting in its entirety so that it might be more closely dissected:

Nurse Sue Ann Duckett was a tall, spare, mature, straight-backed woman with a prominent, well-rounded ass, small breasts and angular, ascetic New England features that came equally close to being very lovely and very plain. Her skin was white and pink, her eyes small, her nose and chin slender and sharp. She was able, prompt, strict and intelligent. She welcomed responsibility and kept her head in every crisis. She was adult and self-reliant, and there was nothing she needed from anyone. Yossarian took pity and decided to help her.

Next morning while she was standing bent over smoothing the sheets at the foot of his bed, he slipped his hand stealthily into the narrow space between her knees and, all at once, brought it up swiftly under her dress as far as it would go. Nurse Duckett shrieked and jumped into the air a mile, but it wasn't high enough, and she squirmed and vaulted and seesawed back and forth on her divine fulcrum for almost a full fifteen seconds before she wiggled free finally and retreated frantically into the aisle with an ashen, trembling face. She backed away too far, and Dunbar who had watched from the beginning, sprang forward on his bed without warning and flung both his arms around her bosom from behind. Nurse Duckett let out 
another scream and twisted away, fleeing far enough from Dunbar for Yossarian to lunge forward and grab her by the snatch again. Nurse Duckett bounced out across the aisle once more like a ping-pong ball with legs. Dunbar was waiting vigilantly, ready to pounce. She remembered him just in time and leaped aside. Dunbar missed completely and sailed by her over the bed to the floor, landing on his skull with a soggy, crunching thud that knocked him cold.

He woke up on the floor with a bleeding nose and exactly the same distressful head symptoms he had been feigning all along. The ward was in a chaotic uproar. Nurse Duckett was in tears, and Yossarian was consoling her apologetically as he sat beside her on the edge of a bed. The commanding colonel was wroth and shouting at Yossarian that he would not permit his patients to take indecent liberties with the nurses. (302)

The opening paragraph suggests several aspects of how readers are meant to view what follows. Similar to his manner of introducing Lieutenant Scheisskopf's wife, Heller begins by describing Nurse Duckett's stature, then moves on to her sexual features, her face, and last of all her personality, encouraging the reader to view Nurse Duckett primarily as a sexual object by placing her body at the forefront. Furthermore, after describing Nurse Duckett in terms of her independence, maturity, and "ascetic" features (which suggest an austere abstention from sex), Heller notes that Yossarian "took pity and decided to help her," one of countless apparent contradictions in the novel, but one that here signals Nurse Duckett's independence as a negative trait to be remedied. The description reinforces the male-centric notion of women existing primarily for men's pleasure by making female self-sufficiency the object of satirical attack, placing the assault in the context of Yossarian's attempt to remove that selfsufficiency and normalize a male-centered power dynamic.

The second paragraph uses the animated language of the novel to describe both Yossarian and Dunbar's assault ("slipped his hand stealthily," "sprang forward on his bed without warning") and Nurse Duckett's reaction ("jumped into the air a mile," "bounced out across the aisle once more like a ping-pong ball with legs") in a manner that further suggests the scene is meant to be taken lightly. Hidden among such phrasing are descriptions of Nurse Duckett's "ashen, trembling face" as she "retreated frantically" along with her multiple screams, but with so much of the paragraph centered on Yossarian and Dunbar, Nurse Duckett's response, and any attempt to elicit reader sympathy, are buried and ultimately lost. On the contrary, Heller's description of Nurse Duckett during the assault focuses mainly on her physical movements in the hospital aisle ("she squirmed and vaulted and seesawed," "bounced out across the aisle once more"), rather than her internal reactions.

9 The third paragraph includes an uncharacteristic narrative moment where the perspective shifts briefly to Dunbar, likely a contrivance for fast-forwarding several minutes to avoid showing Nurse Duckett and Yossarian's reactions as the assault is broken up. When the scene resumes Yossarian is shown "consoling [Nurse Duckett] apologetically," which outwardly suggests both that Yossarian is sorry for what he has done (though no such indication is given for Dunbar) and that the two are making amends. However, Yossarian's remorse is never shown in detail, nor are the specifics of said amends, perhaps because any attempt to do so would be viewed as unbelievable. An unnamed colonel (only later identified) is "wroth and shouting," suggesting disapproval from above, but because this disapproval is placed within the vague rantings of a minor character rather than within the narration, it lacks conviction and is easily dismissed as blustering nonsense, particularly because readers have come to 
view other colonels such as Cathcart and Korn as unworthy of their trust. The only other character to take the assault seriously is the psychiatrist Major Sanderson, whose credibility Heller first mocks by lampooning his preoccupation with fish dreams, then completely destroys by having him voice his hidden desire to "grab some naked bitch by the neck" (305) and assault a woman in a more explicitly violent manner. Such treatment paints the psychiatrist as hypocritical and frames Yossarian's assault, in contrast to this more outward misogyny, as an instance of innocent fun.

10 All told, the scene does little to denote the assault as a serious act of sexual violence and is instead followed by the unlikely relationship between Yossarian and Nurse Duckett forty pages later, where Nurse Duckett "found Yossarian wonderful" (346) and "loved to make him burn and suffer till dark, then satisfy him" (347), placing Yossarian's pleasure at the forefront of their relationship. In discussing Yossarian's relationships with women, David Seed focuses primarily on Nurse Duckett's "importance as emotional refuge" from the chaos of death and destruction in Chapter 30 when Kid Sampson and McWatt are killed, and posits that Heller keeps their relationship brief to avoid "repeating Hemingway" (31). By all accounts, the hospital assault's placement in the novel suggests that its main purpose is to serve as a stepping stone to Yossarian and Nurse Duckett's short-lived affair, a plot development that fails to satisfy because the missing few minutes of Yossarian's apology are never shown, leaving readers confused about how their relationship matured into regular beach dates. Another interpretation is that the scene provides Yossarian with a reason for being sent to an absurd, misogynistic psychiatrist to provide a chance for satire, though in a novel preoccupied with insanity Heller might have found any number of other ways to accomplish this. One final explanation for the scene's inclusion is thematic, in that Yossarian's expressing desperate, physical lust for a ward nurse shows his unceasing sexual desires akin to his lusts for life and freedom just as he later reaches out for Nurse Duckett on the beach, thus emphasizing character traits relevant to the central narrative. However, Yossarian's reckless sexuality is less problematically developed elsewhere, as in the scenes where he consensually sleeps with Lieutenant Scheisskopf's wife in open defiance of a superior officer who could easily do him harm.

The conundrum of how readers should view the hospital assault raises questions about how we should teach, discuss, and adapt Catch-22 today, particularly with younger audiences who might not be as well-informed about rape and consent. When readers see past the novel's casual treatment of Nurse Duckett's assault and instead view the scene as an unrebuked abuse of male power, it places them in the awkward position of siding against Yossarian and Dunbar as abusers, turning them into momentary embodiments of Nagel's corrupt and ridiculous enemy before they return to their roles as virtuous victims. However jarring this reading may seem, separating the scene as troublingly inconsistent with the novel's other portrayals of assault is preferable to glossing over Yossarian's act or attempting to justify its existence. One model for how this contradiction can be acknowledged and Yossarian's actions rebuked can be found in the contemporary version of the Catch-22 CliffsNotes study guide, a resource aimed at students that takes a firm stance against Yossarian's behavior. Its discussion of the assault states that "if Yossarian's assault on Nurse Duckett, whom he barely knows at this point, is meant to be amusing, it presents a problem of interpretation unlike any other in the novel" that "has to alter our evaluation of the previously lovable protagonist" ("Chapters 27-28"). This altered evaluation, however, never carries over into the guide's other assessments of Yossarian's character, ${ }^{1}$ suggesting that the 
problem of interpretation is isolated solely within the Nurse Duckett scene. In a striking comparison to the events of the Eternal City chapter, the guide also notes that Yossarian's assault "sounds more like something that Aarfy would do" ("Chapters 27-28"), explicitly linking Yossarian with the novel's more detestable characters who enact harm on others and forcing readers to momentarily place him in the role of abuser and corrupt villain within this one scene. ${ }^{2}$

Discussing these problems of interpretation directly in this manner exemplifies how we can view the Nurse Duckett assault as incongruous with Heller's more human-centered thematic development of rape as a horrifying abuse of power. It is in these instances where the severity of assault is ignored that Heller's portrayals play into the same power abuses he elsewhere condemns, and therefore deserve rebuke. In this sense, the juxtaposition of the Nurse Duckett assault in the novel among more clearly condemned instances of assault suggests the manner in which social values have changed since Catch-22's publication, where what was once openly portrayed as humorous can now rightly be singled out as destructive, setting a precedent for identifying and condemning other literary assaults that were once normalized by their authors. Rather than allowing these normalized instances to dominate discussions of women and assault in Catch-22, separating them as inconsistent allows for further discussion of assault in Heller's work overall as a thematic embodiment of power abuse, which will be the focus of the remaining sections.

\section{The Eternal City Walk and Sexual Assault as Abuse of Power}

13 A close examination of Catch-22's Eternal City chapter reveals how Heller links rape more closely with other attacks by those in power against those who have none. These moments occur after the military police chase all of the women out of the apartment in Rome and Milo becomes enamored with smuggling illegal tobacco rather than helping Yossarian locate Nately's whore's kid sister. While walking the streets Yossarian encounters scenes of unspeakable cruelty, including child poverty; the beating of first a dog, then a child; a man whose teeth have been knocked out; the gang rape of an unnamed woman by Allied soldiers; and Aarfy's rape and murder of the maid Michaela. The two rapes shown in the chapter alongside "the shivering, stupefying misery in a world that never yet had provided enough heat and food and justice for all but an unscrupulous handful" (421) place sexual assault squarely within the dynamic of social injustice where Heller's "unscrupulous handful" wreaks havoc over the masses, serving the author's purpose of heightening the scene's horror and pathos.

14 In his critical study, The American Novel of War, Wallis R. Sanborn III analyzes both rapes as embodying the "oppositional dyad between occupiers and local peoples" (157) that manifests in times of military occupation. Sanborn's viewing of the rapes through the lens of occupying soldiers abusing powerless victims accounts for one of many such dyads in the novel between the powerful and the oppressed: higher-ranking officers over lower-ranking officers, rich over poor, military police over civilians, and so on. These labels, rather than being mutually exclusive, complement one another, overlapping throughout the novel to show the multiple avenues through which power manifests: Milo Minderbinder, for instance, enjoys both the privileges of an occupying soldier and the monetary power gained by his control over an international trading 
syndicate. Power likewise takes the dual form of occupying soldier and rapist during the rape of the unnamed woman, where Heller repeats the woman's slurred cries of "Pleeshe don't" (423) to emphasize her lack of consent and evoke readers' sympathy for her as an unwilling victim. The drunken soldier's urging "determinedly" (423), in turn, emphasizes his role as abuser in which his sexual desires take precedence over the victim's autonomy. When juxtaposed against Heller's other imagery of shattered teeth, horrifying scars, and disfiguring burns on the Eternal City's residents, the incident suggests the permanent effects of sexual assault, and as Sanborn asserts, "the destructive psychological effects of group sexual assault will forever affect the victim" (157).

The second instance of assault, that of Aarfy's rape and murder of the maid Michaela, forms the chapter's climax in what Minna Doskow in her analysis of Catch-22's night walk calls "the final resolving chord of a demonic crescendo that has been building throughout the journey" (191). Unlike the unnamed woman and soldiers in the previous rape, here Sanborn notes that both victim and perpetrator are named, thus humanizing them (157) and placing the crime more solidly within the novel's intricate network of character relationships. Because Michaela has been only briefly mentioned earlier in the novel as "the skinny maid with the merry disposition" (162), Heller adds more details immediately before the appearance of her dead body, describing her as a "happy, simple-minded, hard-working girl" oblivious to the men's dirty remarks, who "giggled with childish joy because she understood no English and thought they were flattering her and making harmless jokes" (427). Doskow writes that this description of Michaela as naïve and innocent makes her, for Yossarian, "the one apparent departure from universal deformity and perversion" (190) established during the night walk, serving briefly as a symbol of hope before she is immediately sacrificed to those same perversions.

Heller himself has described the horrors of the Eternal City night walks as representing inactivity in the face of tragedy ("UCLA"), with the scene's focus narrowed on Yossarian as observer to the horrors around him. In the case of sexual assault, such filtering of the victim's experience through a male observer captures only a superficial, pathosinducing perspective, with Michaela's lack of real development or agency ultimately limiting the reader's ability to view her in any role beyond that of innocent victim and her rape and murder as little more than a tragedy. Heller's added character development, brief as it is, comes too late to convey a sense of real loss, and Michaela's status as a named character raises her only marginally above the unnamed female victim on the street. Rather than attempting to account for Michaela's experience during or after the rape, Heller focuses most closely on her physical treatment and the brutality of her murder, describing Aarfy's holding her prisoner with his hand clamped over her mouth followed by "the pitiful, ominous, gory spectacle of the broken corpse" (427) on the street below. While these linguistic choices do little to develop Michaela's experience as victim, they do succeed in placing rape squarely within the horrifying ranks of power abuse, forming a thematically consistent portrayal of the act's brutality that ultimately falls short of fully exploring the horrors of assault. 


\section{Sexual Assault and the Veneer of Social Distinction}

Heller's more substantial attention to Aarfy as a serial abuser of women, however, allows for greater insight into the novel's disgusted stance against those who commit rape, along with the avenues taken by rapists to escape punishment. Critics of Catch-22 share a united condemnation of Aarfy: Sanborn writes of him exhibiting "nihilism" (158), Nagel singles out his character as embodying "depravity" ("Angry Humor" 101) and calls him "the most blind and corrupt character of all" (103), and J.P. Stein calls him Yossarian's "true antagonist" (213), pairing him with the more outwardly sadistic Captain Black as one of two "men without feeling" (204). Walter McDonald in his discussion of names in Catch-22 agrees that Aarfy is "the most despicable one in the book," pointing out that the longer version of his name, "Aardvark" can be rendered as "earth-pig" (19) and embodies his base nature. ${ }^{3}$ Jean Kennard further cites Aarfy's escape from punishment as an example from a world where "the rules do not work" and there is "no reasonable justice" (77) because the more serious crimes of rape and murder are overlooked in favor of Yossarian's not having a leave pass.

Aarfy's depravity, rather than springing from an outwardly villainous persona, lies hidden behind his exterior of superficial distinction, with his pipe-smoking, collegeeducated character appearing to embody middle-class values of sophistication and upstanding citizenry. This practice of outwardly embracing traits valued by society while exhibiting vile characteristics off the record is demonstrated by multiple characters in Catch-22 and contributes to its absurd quality; Havermeyer, for instance, is singled out as the best bombardier in the squadron, loyal to his superior officers and married with a child at home, but he spends his nights sadistically shooting field mice with a stolen gun, laughing while "showering the rank, furry body [of a mouse] all over the tent with a reverberating crash" (32). Heller initially sets up Aarfy as exhibiting a similar air of respectability in his relationships with women by having him eschew prostitutes and appear to look out for the well-being of "nice girls" (161), though his later speech about casually assaulting two unnamed high-school girls in his fraternity days paints a very different picture:

'I remember one day we tricked these two dumb high-school girls from town into the fraternity house and made them put out for all the fellows there who wanted them by threatening to call up their parents and say they were putting out for us. We kept them trapped in bed there for more than ten hours. We even smacked their faces a little when they started to complain. Then we took away their nickels and dimes and chewing gum and threw them out. Boy we used to have fun in that fraternity house,' he recalled peacefully, his corpulent cheeks aglow with the jovial, rubicund warmth of nostalgic recollection. (246)

There are a number of revolting things about this speech: Aarfy's derisive manner of describing the victims as "dumb," the fraternity members' blackmail and threat of parental shame, the egregious length of the assault, the physical smacking, the robbery, and the childlike quality of the girls suggested by the mention of their "nickels and dimes and chewing gum." Contrasted with this cruelty is Aarfy's casual, nostalgic manner of recalling the incident, which he does "peacefully" and with a face radiating "rubicund warmth," belying the severity of what has occurred. Such outward appearances of friendliness and dignified nostalgia suggest that acts of assault can be overlooked if assailants frame events as innocent instances of good fun-note, for example, Aarfy's use of the adolescent euphemism "put out" to create the impression of 
consent. The franker, more clearly appalling details of the assault, however, allow Yossarian and readers to see past the charade and identify the crime. Heller makes this charade more explicit after Michaela's murder when Aarfy repeats "They're not coming to arrest me. Not good old Aarfy" (428), placing confidence in his belief that his appearance of respectability will protect him from societal punishment. ${ }^{4}$ That the military police do ignore Aarfy's crime and apologize to him for intruding suggests the extent to which law enforcement and other authority figures are willing to accept a veneer of social distinction as justification for overlooking sexual assault.

Much of Aarfy's ostensible respectability stems from his status as a fraternity alumnus, a thematic choice by Heller that casts light on the pervasiveness of sexual assault by fraternity members. Even at the time Heller was writing Catch-22 data was beginning to emerge regarding fraternities and rape, with a 1957 study of sexual assault on college campuses finding that fraternity men were overrepresented in reported incidents of unwanted sexual intimacy (Kirkpatrick and Kanin 55). Research in subsequent decades has found that fraternity men are more likely to "plan and execute strategies aimed at obtaining sexual gratification" at both "individual and collective levels" (Martin and Hummer 468), that group loyalty among fraternity members creates a permissive atmosphere of secrecy allowing rape to go unpunished (Schwartz and DeKeseredy 122), and that even in recent years men who join fraternities are more likely to endorse rape myths (Seabrook et al. 514). So too has Aarfy's fondness for "nice girls" (161) been substantiated by research that fraternity men are preoccupied with sociability, charm (Stombler and Martin 156), and financial affluence (Martin and Hummer 461); Heller mocks this last trait by having Aarfy attempt to date a Red Cross girl whose only defining characteristic is that her father "owned an important milk-of-magnesia plant" (296), implying a superficiality doomed to failure when Aarfy gets lost on his way to the date. The novel's biting treatment of fraternity-related abuses is one of Heller's many criticisms targeted at groups outside of the military, such as Chief White Halfoat's family being repeatedly forced to leave their homes due to oil drilling, a thinly veiled reproach of the treatment Native Americans have received at the hands of oil companies and the federal government. These criticisms extend Heller's social commentary beyond the time and place of the novel to cast light on institutionalized injustices throughout other facets of society.

21 Finally, while most of the characters in Catch-22 embody E.M. Forster's notion of flat characters centered around a single idea or trait (47), Aarfy's nervous discomfort after Michaela's rape and murder moves him beyond a mere caricature of an oblivious rapist by suggesting both an awareness of his crime and a conscious need to maintain his veneer of respectability as a safeguard against punishment. Though he continues to protest that the police aren't coming to arrest "good old Aarfy," in contrast to his earlier boasts about the fraternity assault Heller has him show a "forced smile" during his denials, notes in the next paragraph that "his nervousness increased," and finally has him look "sick" and fall into a "trembling stupor" (428) as the sounds of the approaching police grow louder. While such unconsciously exhibited signs of guilt initially contribute to readers' expectation that Aarfy will be arrested, they also reveal that his air of cheerful obliviousness is a mask, with Aarfy understanding both the severity of his crimes and their possible consequences as he uses the "good old Aarfy" persona as a calculated defense against punishment. This awareness transforms Aarfy from an oblivious imbecile into a manipulative actor unable to keep up his façade; an 
insight into the level of perception experienced by rapists regarding their crimes and the measures they take to escape punishment.

Though Heller's attention to the characteristics of rapists and the strategies they implement does a great deal to move the novel's assaults beyond mere shock value, these assaults ultimately retain an air of superficiality without similar insight into the trauma of the victims, whose suffering, as in the case of Michaela, is used solely to signal tragedy rather than being explored more significantly. This missing aspect of Heller's treatment can best be observed in Something Happened, where more substantial attention and agency is given to a female assault victim.

\section{Characteristics of Rape Trauma in Something Happened}

Something Happened is narrated by Bob Slocum, a middle-aged executive who serially cheats on his wife, is estranged from his children, and is determined to obtain a promotion while hauntingly wondering where his life took a turn for the worst. Though the structure of Something Happened-consisting of Slocum's rambling, acerbic, and fearful narration-is drastically dissimilar to that of Catch-22, the novel contains similar dynamics of power, with Slocum himself functioning in his workplace as both a fearful victim of the corporate world's psychological assaults and a bully who himself takes advantage of the people below him for personal gain. As an adult Slocum is a detestable figure who is cruel to his family and brutal in manners of sex-in addition to his numerous affairs, he admits that rape "intrigues and excites" (447) him and speaks of forcing his wife to have sex "at times when she doesn't want to" (407), admissions that place him on the villainous side of an uneven sexual power dynamic. However, Slocum also spends much of the novel pining for his younger self, the "nice-looking, polite, seventeen-year-old boy with a good sense of humor" (465) he used to be, when he was less experienced and fell on the sympathetic end of the power spectrum. Though Slocum's recollections of his adolescence are colored by his adult neuroses and nostalgia, these accounts reveal Heller's more careful, victim-focused treatment of sexual assault through the character of Virginia Markowitz, the flirtatious older girl slocum befriended as a teenager while working at an auto insurance company.

Despite her prominence in the novel, little has been written about Virginia apart from Slocum's obsessive attachment to her memory. Nicholas Canaday notes that rather than serving as a romantic ideal for the troubled slocum, she is simply "a girl he could not get" (35), focusing on Slocum's youthful pursuit of her as a contrast to his current affairs. In contrast, Judith Ruderman posits that Slocum's infatuation "is not so much a lament for missed opportunities as it is an elegy for lost potency" (64), though she too adopts a Slocum-centered approach by neglecting to analyze Virginia's character independently. Virginia is twenty-one (four years older than Slocum) during the period of the novel's flashbacks, and before Slocum meets her she was a student at Duke University. While at Duke she was the victim of a gang rape involving five football players, a traumatic incident that Sanford Pinsker callously calls a "steamy tale" (70) and that Nagel dismisses with the euphemism that Virginia "entertained five members of the football team in a dormitory room" ("University" 21). Virginia tells Slocum that after the rape she was "expelled" and sent home $(361),{ }^{5}$ and that some time later her father committed suicide and she didn't return to school; Nagel seems to confuse the 
order of these events by blaming Virginia's departure from Duke on her father's suicide rather than the rape ("University" 21), whereas in the novel Slocum elsewhere suggests that her father's suicide is the reason she "never went back" (77). While working at the insurance company Virginia is a target of unwanted sexual advances from her coworkers, including attempted assaults in cars and an attempted gang rape in the storeroom that Slocum succeeds in breaking up; though she confides her disgust about the former incidents to Slocum in private, after the attempted storeroom rape she goes back to flirting with her assailants in the office as if nothing had happened. Virginia then goes on to commit suicide in the same manner as her father before the age of twenty-five, an act Slocum self-centeredly views as making it impossible for them to consummate their relationship.

While the majority of the Virginia scenes focus on Slocum's youthful adoration and his viewing of her as a romantic conquest, beneath his self-centered narration lies Heller's more compassionate, well-rounded treatment of Virginia and her trauma. In contrast to his reliance on shocking imagery to convey the severity of the rapes in Catch-22 through the male gaze, Heller has Virginia recount her own assault by the football players and leads readers to make their own interpretations about its tragic consequences. While Slocum again occupies the role of male observer, his observations and commentary offer substantially more revealing insight into Virginia's experience. There exists a great deal of contemporary research on rape victims' experience with post-traumatic stress disorder (PTSD) (Chivers-Wilson 112), and many of Virginia's reactions indicate signs of rape trauma syndrome (RTS), which was first categorized in the mid-1970s around the time of Something Happened's publication. Following an initial stage of recovery after the attack, victims of rape trauma syndrome will often undergo a longer-term process of reorganization as they attempt to get their lives back together and put the experience behind them (Burgess and Holmstrom 982, McCombie 154). Slocum's accounts show Virginia exhibiting several characteristics that would place her in this reorganizational stage, including her desire to escape the scene of the assault (Burgess and Holmstrom 983) by returning home, and her seeking out support networks of friends outside her family (McCombie 155) by confiding in young Slocum about the rape. As early as 1970 researchers also noted the tendency of young women who experience rape to insist that the incident remain a secret from their parents (Sutherland and Scherl 505), with Virginia similarly avoiding telling her parents as indicated by her admission that "I never found out whether [Duke University] told my father" (361) before his suicide.

Though Virginia is able to discuss the Duke rape with Slocum, her recounting is inconsistent and demonstrates the denial, suppression, and rationalization characteristic of rape victims in the reorganizational stage (Sutherland and Scherl 507). Though she initially uses the phrases "They made me," "I didn't want to" (361), and "They held me down" (443), she denies Slocum's insinuation that the incident was rape and insists that "It was fun once we started" (361) and "I'd like to do something like that again sometime soon" (362). Her rationalization is not entirely convincing for young Slocum, who walks away with the thought that the football players "treated her like crap" (362), providing a clearer takeaway for how readers should view the incident. The exchange suggests that Virginia's cheerful account of the Duke rape-and by extension, the rest of her suggestive office banter-are defense mechanisms underscoring the sexual trauma lying beneath them; as the incident takes place in the early 1940s long before second-wave feminism, it is unlikely that Virginia would 
possess sufficient language and context in which to adequately express her trauma. In her accounts to Slocum of the attempted assaults by her coworkers she's able to show more consistent revulsion and fear, telling the story with "shaken" poise and complaining in "a tone of petulant protest that was not typical of her" before saying she was "insulted" (342), implying her ability to convey honest judgements about incidents after the Duke rape when confiding in a close support network. From these conversations Slocum once again takes away a clear measure of concern for Virginia's well-being, saying that she "could not ever feel safe again" (341) with the coworker who attempted to rape her, another signal to readers regarding the lack of safety experienced by women after forceful sexual advances.

Denial as a defense mechanism after the Duke rape also explains Virginia's contradictory behavior during her office trysts with slocum, where she accepts his invitations to come into the hallway then breaks off their encounters after foreplay begins. Her behavior is consistent with rape victims who exhibit symptoms of fear and panic upon attempting to resume normal sexual relations (Burgess and Holmstrom 984), with Virginia's panic especially jarring when juxtaposed against her bawdy jokes and endorsement of the promiscuous atmosphere of the office. Virginia is seized with "a stark, mysterious terror" (73) and goes "wild with fright" (345) at her moments of turning away from foreplay, and Slocum recalls her telling him "You scare me" (346). Her "swift, sullen emotional changes" (445) also show evidence of a woman unable to keep up the façade of her denial: "she would glare at me in savage outrage as though I were someone who was trying to cheat her" (445), Heller writes in a moment that suggests Virginia's placement of young Slocum in the position of an assailant. Heller's description of her as "tricked, seduced, and violated" (446) during these moments more specifically evokes the image of a rape victim even as the adult slocum callously dismisses her as "slightly crazy" (444) or "a little bit nuts" (362). Her behavior also suggests a need for control over these sexual encounters, first by provoking them, then by breaking away, made evident in her initial boast during the attempted storeroom rape that "I could handle you all" (447). This desire to control sexual situations is clear to Slocum even as its link to rape trauma remains elusive, and is best summed up in his observation that "She did not like me to do things to her; she liked to do things to me" (77).

28 Similarities between the rapes in the two novels suggest that the assaults in Something Happened form a more developed, multifaceted treatment of those in Catch-22, with both contributing to thematic developments of power abuse in their respective novels. Just as Aarfy is a member of a fraternity, the Duke rape is perpetrated by football players, another university-associated group that enjoys high social status among the middle class but creates an all-male environment that can lead to the objectification of women (Schwartz and DeKeseredy 125). Again, Heller's placement of football players in the position of rapists was supported by research in subsequent decades showing college athletes to be the second-most-common group after fraternities to be implicated in gang rapes (Neimark 197) and to have a higher-than-average association with rape overall (Fritner and Rubinson 280), particularly the likelihood of using physical force to obtain sex (Boeringer 141). In contrast to the adult Slocum's idealized image of the "AllAmerican football player" (1) held up as a standard for success he cannot achieve, ${ }^{6}$ the nameless Duke football players are "hulking" and "primitive" (446), implying both a primal desire to act on their sexual urges and physically placing them at the dominant end of a power dynamic similar to those in Catch-22. ${ }^{7}$ Similar to the unnamed woman's 
cries of "Pleeshe don't" (423) during the Eternal City rape, Heller shows Virginia's fear and elicits reader sympathy during the attempted storeroom rape through her protests of "Let me go" and "Stop now. Please" (449). The tendency of rapists to intentionally disguise their actions as innocent fun is further echoed in the attempted storeroom rape through the assailants' attempt to "sustain the pretense that it was all only a bit of horseplay that ought not to be misunderstood" (448). Heller takes this idea a step further by having the adult Slocum note in a parenthetical that he too "learned for the future to execute variations on the same masquerade from them" (448), implying that the charade of innocence and consensual fun is a learned technique for controlling women that younger men learn by observing older men. Heller also treats young Slocum's rescue of Virginia with a lack of sentimentality similar to the lack of justice after Michaela's rape, when, though readers may expect Virginia to shower Slocum with approval after her rescue, she instead returns to flirting with her assailants in the office, leaving Slocum "not allowed to feel like her hero for long" (451). Both incidents imply that bystander involvement is useless, that rape occurs behind the veneer of public respectability, and that justice will not be served for victims.

Such similarities suggest that sexual assault as an abuse of power in Catch-22 is echoed and more thoroughly developed in Something Happened, primarily through the exploration of its effects on a female victim. This understanding of assault as a manifestation of power in both novels can contribute to a greater understanding of the relationships between powerful individuals and sympathetic victims in Heller's novels that "reveal the destructive or illegitimate aspects of post-World II social structures" (Templeton 13), and that extend to other times and places in novels such as Good as Gold, Picture This, and Closing Time.

\section{Conclusion: Contemporary Discussion of Assault in Catch-22}

30 While it should come as no surprise that the 2019 Catch-22 miniseries omits Yossarian's assault on Nurse Duckett, ${ }^{8}$ it also delivers a more obvious condemnation of Aarfy's fraternity gang rape of the two high school girls, with the old man swiftly rebuking Aarfy's story to eliminate any risk of viewer misinterpretation. Aarfy's rape of Michaela is meanwhile framed more explicitly as a denial on the part of military authorities, with the MPs dismissing the crime as a civilian matter despite Yossarian's protests and their clear view of the scene. The miniseries also takes the step of extending the coverup through the upper echelons of the military, with Colonel Korn's offer in the novel of sending Yossarian home in exchange for positive PR changed to the more overtly odious agreement that Yossarian keep Aarfy's crime a secret to protect the military's reputation. ${ }^{9}$

31 In this case, as in others, those approaching Catch-22 in a contemporary landscape are tasked with separating the superficial and obliviously misogynistic treatment of the novel's female characters, particularly the assault on Nurse Duckett, from its more carefully developed themes of sexual assault as an abuse of power. While these later instances can and do cast relevant light on sexual assault today, those seeking to share Catch-22 with new generations of readers would be wise to follow the example of the contemporary CliffsNotes discussion of the hospital assault by discussing these 
conflicting portrayals of assault directly and condemning their attempt to normalize vile behavior.

\section{BIBLIOGRAPHY}

Boeringer, Scot B. "Influences of Fraternity Membership, Athletics, and Male Living Arrangements on Sexual Aggression.” Violence Against Women, vol. 2, no. 2, 1996, pp 134-147.

Burgess, Ann Wolbert and Lynda Lytle Holmstrom. "Rape Trauma Syndrome." American Journal of Psychiatry, vol. 131, no. 9, 1974, pp 981-986.

Canaday, Nicholas. "Joseph Heller: Something Happened to the American Dream." CEA Critic, vol. 40, no. 1, 1977, pp. 34-38.

Catch-22 (film). Directed by Mike Nichols, Paramount, 1970.

Catch-22 (TV mini-series). Created by Luke Davies and David Michôd, Anonymous Content, 2019.

Chivers-Wilson, Kaitlin A. "Sexual Assault and Posttraumatic Stress Disorder: A Review of the Biological, Psychological, and Sociological Factors and Treatments." McGill Journal of Medicine, vol. 9, no. 2, 2006, pp. 111-118.

Doskow, Minna. "The Night Journey in Catch-22." Twentieth Century Literature, vol. 12, no. 4, 1967, pp. 186-193.

Forster, E.M. Aspects of the Novel. 1927. Aspects of the Novel and Related Writings, edited by Oliver Stallybrass, Abinger, 1974.

Fritner, Mary Pat and Laurna Rubinson. “Acquaintance Rape: The Influence of Alcohol, Fraternity Membership, and Sports Team Membership." Journal of Sex Education and Therapy, vol. 19, no. 4, 1993, pp. 272-284.

Heller, Joseph. Catch-22. Dell, 1961.

---. "Joseph Heller at UCLA." 8 April, 1970, University of California, Los Angeles. Lecture. Youtube, uploaded by UCLACommStudies, 14 Jan 2014. <https://www.youtube.com/ watch? $\mathrm{v}=\mathrm{xJ} 5 \mathrm{Jpozwg} 8 \mathrm{E} \& \mathrm{t}=1 \mathrm{~s}>$.

---. Something Happened. Ballantine, 1974.

Holloway, Daniel. “How George Clooney and Christopher Abbott Battled to Bring 'Catch-22' Into the 21st Century." Variety, 23 April 2019. Accessed 14 April 2020. https://www.variety.com/2019/ tv/news/george-clooney-catch-22-christopher-abbott-1203194665.

Kennard, Jean. “Joseph Heller: At War with Absurdity.” Mosaic: An Interdisciplinary Critical Journal, vol. 4, no. 3, 1971, pp. 75-87.

Kirkpatrick, Clifford, and Eugene Kanin. "Male Sex Aggression on a University Campus." American Sociological Review, vol. 22, no. 1, 1957, pp. 52-58.

Lloyd, Robert. “Review: Why George Clooney's ‘Catch-22' for Hulu May Make You Yell at the Screen.” Los Angeles Times, 16 May 2019. Accessed 14 April 2020. https://www.latimes.com/ entertainment/tv/la-et-st-catch-22-hulu-review-20190516-story.html. 
Martin, Patricia Yancey and Robert A. Hummer. "Fraternities and Rape on Campus." Gender and Society, vol. 3, no. 4, 1989, pp. 457-473.

McCombie, Sharon L. "Characteristics of Rape Victims Seen in Crisis Intervention." Smith College Studies in Social Work, vol. 46, no. 2, 1976, pp. 137-158.

McDonald, Walter. "Look Back in Horror: The Functional Comedy of Catch-22." CEA Critic, vol. 35, no. 2,1973 , pp. 18-21.

Miller, Liz Shannon. “'Catch-22': Hulu's Big Prestige TV Bet Might Have a Natural Audience Teenage Girls.” IndieWire, 15 May 2019. Accessed 14 April, 2020. https://www.indiewire.com/ 2019/05/catch-22-hulus-big-prestige-tv-bet-might-have-a-natural-audience-teenagegirls-1202141265.

Moore, Matthew. “Clooney Revamps 'Misogynistic' Catch-22 for TV.” The Times, 24 April, 2019. Nagel, James. "Catch-22 and Angry Humor: A Study of the Normative Values of Satire." Studies in American Humor, vol. 1, no. 2, 1974, pp. 99-106.

---. “The 'Catch-22' Note Cards.” Studies in the Novel, vol. 8, no. 4, 1976, pp. 394-405.

---. “Joseph Heller and the University.” College Literature, vol. 10, no. 1, 1983, pp. 16-27.

Neimark, Jill. "Out of Bounds: The Truth About Athletes and Rape." Mademoiselle, vol. 97, no. 5, 1991, pp. 196-199, 244-246.

Peek, Charles A. "Character Analysis: Yossarian." CliffsNotes on Heller's Catch-22. CliffsNotes Study Guides. Accessed 14 April 2020. https://www.cliffsnotes.com/literature/c/ catch22/characteranalysis/yossarian.

---. CliffsNotes on Heller's Catch-22. Houghton Mifflin Harcourt, 1975.

---. "Summary and Analysis: Chapters 27-28." CliffsNotes on Heller's Catch-22. CliffsNotes Study Guides. Accessed 14 April 2020. https://www.cliffsnotes.com/literature/c/ catch22/summary-andanalysis/chapters-2728.

Pinsker, Sanford. Understanding Joseph Heller. Columbia, 1991.

Reilly, Charlie. “An Interview with Joseph Heller." Contemporary Literature, vol. 39, no. 4, 1998, pp. 507-522.

Ruderman, Judith. Joseph Heller. Continuum, 1991.

Sanborn, Wallis R., III. The American Novel of War: A Critical Analysis and Classification System. McFarland \& Company, 2012.

Schwartz, Martin D., and Walter S. DeKeseredy. Sexual Assault on the College Campus: The Role of Male Peer Support. Sage Publications, 1997.

Seabrook, Rita C., Sarah McMahon, and Julia O'Connor. “A Longitudinal Study of Interest and Membership in a Fraternity, Rape Myth Acceptance, and Proclivity to Perpetuate Sexual Assault." Journal of American College Health, vol. 66, no. 6, 2018, pp. 510-518.

Seed, David. The Fiction of Joseph Heller: Against the Grain. St. Martin's Press, 1989.

Stern, J.P. "War and the Comic Muse: The Good Soldier Schweik and Catch-22." Comparative Literature, vol. 20, no. 3, 1968, pp. 193-216.

Stombler, Mindy and Patricia Yancey Martin. "Bringing Women In, Keeping Women Down: Fraternity 'Little Sister' Organizations.” Journal of Contemporary Ethnography, vol. 23, no. 2, 1994, pp. 150-184. 
Sutherland, Sandra and Donald J. Scherl. "Patterns of Response Among Victims of Rape." American Journal of Orthopsychiatry, vol. 40, no. 3, 1970, pp. 503-511.

Templeton, Peter. “'Why Don't You Just Say It as Simply as That?': The Progression of Parrhesia in the Early Novels of Joseph Heller." European Journal of American Studies, vol. 11, no. 2, 2016, https://journals.openedition.org/ejas/11573. Accessed 15 May 2020.

Way, Brian. "Formal Experiment and Social Discontent: Joseph Heller's Catch-22." Journal of American Studies, vol. 2, no. 2, 1968, pp. 253-270.

\section{NOTES}

1. For example, the guide's character analysis of Yossarian notes that his "relationships with women are assuredly less than heroic" but does not include the Nurse Duckett assault in its examples of his lascivious behavior.

2. This interpretation can be found in the updated online version of Charles A. Peek's original 1975 CliffsNotes study guide, which, though it does describe the hospital scene as a "sexual assault," offers only that Yossarian responds to Nurse Duckett "in an exploitative manner" (31). Such updated language in the wake of changing social norms exemplifies how similarly outdated discussions of classic literary works can be expanded to suit a contemporary sensibility. CliffsNotes publisher Houghton Mifflin Harcourt did not respond to a request for comment on when and in what manner the online text was altered.

3. As McDonald notes, Heller often uses character names to emphasize innate traits: in addition to Aarfy/Aardvark, Appleby's name evokes an apple pie image of American wholesomeness, Orr's captures his choice of escaping to Sweden "or" staying in the war, and Scheisskopf's name, most notoriously, is German for "shithead." (19).

4. The use of naïve innocence to evoke societal sympathy is itself ingrained into Aarfy's name: though the character was originally named "Aarky" (more clearly short for "Aardvark"), Heller renamed him Aarfy during the novel's development to create a softer, puppy-dog effect (McDonald 19).

5. While the details of Virginia's expulsion remain unclear, her account mentions that the rape occurred in the men's dormitory (361), implying that she was discovered by university officials and held responsible for the incident, leading to her being sent home. The university's actions bear similarities with the lack of justice after Michaela's rape and murder in Catch-22 while encapsulating the victim-blaming aspect of rape culture.

6. Slocum learns of Virginia's suicide at age twenty-two when he phones his former workplace pretending to be an old football friend of Virginia's from Duke (456); the lie signals his desire to adapt the persona of her rapists now that he finally feels ready to consummate their relationship. In future calls he goes on to adopt the personas of former wrestling champion and national intercollegiate weightlifting champion (461), an intensification of his wish fulfillment that links other forms of muscular athleticism with hypermasculine power and sexual dominance.

7. Strikingly, slocum also compares one of the assailants in the attempted storeroom rape to his son's gym teacher Forgione (451), another physically powerful man who forces Slocum's son to embrace competition and from whom slocum fears retribution; 
both men seek to bully and control more sympathetic, victimized characters while instilling fear. The comparison also links sexual conquest with the competitive spirit embraced by Forgione in Slocum's son's gym class and signals rape as a form of corrupting overcompetition.

8. It's worth mentioning that the 1970 film version of Catch-22 also omits the assault scene, though without developing Nurse Duckett more significantly. Her character, played by Paula Prentiss, is most memorable for kneeing Yossarian (Alan Arkin) in the testicles to curb his advances on the beach and then giving him medical advice for how to deal with the pain.

9. The idea of covering up Aarfy's rape to preserve American values is more clearly noted by Heller in earlier drafts, which had Aarfy utter the line, "That would have been bad propaganda for our country" (Nagel, "Note Cards" 399).

\section{ABSTRACTS}

Joseph Heller's Catch-22 contains a troubling moment where Yossarian sexually assaults Nurse Duckett in the hospital. The scene, however, contrasts with Heller's clearer condemnations of assault elsewhere in the novel, particularly the rapes in the Eternal City and Aarfy's escape from punishment. Heller builds on this thematic use of assault in Something Happened by having Virginia Markowitz, a rape victim, exhibit more complex symptoms of rape trauma. These more successful treatments of assault as an embodiment of power abuse suggest that the Nurse Duckett assault should be viewed as a conflicting outlier of the assaults Heller elsewhere condemns.

\section{INDEX}

Keywords: Joseph Heller, Catch-22, Something Happened, sexual assault, rape, rape trauma syndrome (RTS), social indignation, adaptation

\section{AUTHOR}

\section{IAN M. ROGERS}

Ian M. Rogers is a fiction writer and graduate of the MA program at the University of NebraskaLincoln. His interests include twentieth-century fiction, Japanese literature, and humor, and he teaches English as a second language with the JET Programme in Toyama, Japan. His scholarly writing has previously appeared in Great Plains Quarterly. 